\title{
LITERATURA COMO TÁTICA: CONSTRUÇÕES E DESCONSTRUÇÕES
}

\section{LITERATURE AS A TACTIC: CONSTRUCTIONS AND DECONSTRUCTIONS}

\section{Vera Lúcia da Silva*}

UFSB

\section{Álamo Pimentel Gonçalves da Silva** \\ UFSB}

Resumo: Este artigo enfatiza a produção literária como tática de desconstrução das representações sobre os povos indígenas e, ao mesmo tempo, tática de construção de outras formas de afirmação identitária. A noção de literatura menor, de Delleuze e Guatarri, articulada à noção de tática, presente nas artes de fazer de Michel de Certeau conferem limiares de análise em regime de conversação com produções literárias indígenas, sobretudo com a obra Metade Cara, metade máscara, de Eliana Potiguara. Além de ressaltar a potência criadora de outras formas de fazer e dizer dos processos de construção da condição indígena no Brasil, o texto aponta alternativas para a compreensão dos conflitos culturais ainda presentes na contemporaneidade brasileira.

Palavras Chave: Literatura; cotidiano; povos indígenas; cultura e educação.

Abstract: This article lays emphasis on literary production as a deconstruction tactic of the indigenous people representations and a construction tactic of different forms of identity affirmation. Deleuze and Guatarri's notion of minor literature, articulated to the notion of tactics present in Michel de Certeau's "arts of doing” offer possibilities of analysis in conversation with indigenous literary works, especially Eliana Potiguara's "Half Face, Half Mask”. Apart from stressing the creative potentiality of other forms of doing and saying about the construction process of an indigenous condition in Brazil, the text points to alternatives for understanding cultural conflicts still present in the country.

Keywords: Literature; daily life; indigenous people; culture and education.

\section{Por uma literatura menor?}

Se quiser falar ao coração dos homens, há de se contar uma história. Dessas onde não faltem animais ou deuses e muita fantasia. Porque é assim - suave e docemente - que se despertam consciências.

(Jean de La Fontaine)

\author{
* Doutoranda do \\ Programa de Pós \\ Graduação em \\ Estado e Sociedade \\ da Universidade \\ Federal do Sul da \\ Bahia e Professora \\ de Língua Portuguesa \\ e Literatura da rede \\ pública estadual de \\ ensino da Bahia, \\ atuando no Centro \\ Territorial de \\ Educação Profissional \\ do Extremo Sul. \\ E-mail: vsilva.lucia@ \\ hotmail.com \\ ${ }^{* *}$ Professor Associado \\ III do Centro de \\ Formação em \\ Ciências Humanas \\ e Sociais e do \\ Programa de Pós \\ Graduação em \\ Estado e Sociedade \\ da Universidade \\ Federal do Sul \\ da Bahia. E-mail: \\ alamopimentelmcz@ \\ gmail.com
}


Deleuze e Guattari (2014), através da leitura de Kafka, nos dão notícias de uma literatura menor, descomprometida com qualquer teleologia universal ou sequer com a biografia de quem a produz a partir da imaginação, do simbólico indecifrável, da ficção estilizada. Tal literatura vai contra a hermenêutica especializada, não se compromete com os códigos e protocolos estabelecidos, compromete-se antes com o desejo de fazer passar algo de uma certa realidade através de suas escritas, para intencionalmente transformar os modos de fazer, inaugurar outras possibilidades de sentir e pensar. Deleuze e Guattari (2014) nos falam de uma literatura como campo político, um experimento, uma potente arma de guerra. Acrescentaríamos aqui, uma aposta. Ou ainda uma tática, no sentido do intelectual francês Michel de Certeau (1998, p. 46-47), ao passo que depende de uma atitude vigilante e astuciosa de “captar no voo" as "possibilidades de ganho”, que “tem constantemente que jogar com os acontecimentos” para transformá-los em “ocasiões”.

É na potência da literatura menor produzida pelos povos indígenas brasileiros que esse artigo investe. Durante séculos foram e ainda, em grande medida, continuam sendo invisibilizados e, por consequência, apagados da história com $\mathrm{H}$ maiúsculo do país, bem como das narrativas locais, uma vez que permanecem apartados dos espaços de poder e narrados como um outro idealizado ou degenerado, mas de qualquer forma incompatível com a proposta de desenvolvimento em curso. Edgard Lander denuncia que há uma

suposição da existência de um metarrelato universal que leva a todas as culturas e a todos os povos do primitivo e tradicional até o moderno. A sociedade industrial liberal é a expressão mais avançada desse processo histórico, e por essa razão define o modelo que define a sociedade moderna. A sociedade liberal, como norma universal, assinala o único futuro possível de todas as outras culturas e povos. Aqueles que não conseguirem incorporar-se a esta marcha inexorável da história estão destinados a desaparecer. (LANDER, 2005, p. 13).

No caso dos povos indígenas brasileiros, o filósofo indígena Daniel Munduruku (2012, p. 27) trata a primeira fase da colonização como exterminacionista, uma vez que o objetivo era claramente "a destruição em massa dos povos indígenas” justificada pela ausência de alma e de humanidade, ou seja, a degeneração do corpo do outro de tal modo que toda violência é tolerada, permitida e, em último caso, incentivada. Para Munduruku (2012, p. 28), o que define essa fase é uma "brutalidade física contra as sociedades autóctones, pelo assassinato de coletividades inteiras, com o propósito de promover uma 'limpeza étnica' que abrisse os caminhos para o progresso e para o desenvolvimento de uma nação dita 'civilizada”.

Na tentativa de organizar a história do extermínio indígena, Munduruku nos conta de um paradigma integracionista que teria sucedido ao que ele primeiro chamou de paradigma exterminacionista, que se caracterizava: 
pela concepção de que os povos indígenas, suas culturas, suas formas de organização social, suas crenças, seus modos de educar e viver eram inferiores aos dos colonizadores europeus, estando fadados ao desaparecimento. Isso sujeitava os indígenas libertos do cativeiro, na qualidade de indivíduos considerados incapazes, à tutela orfanológica, prevista na lei de 27 de outubro de 1831, como forma de protegê-los, prover seu sustento, ensinar-lhes um ofício e, assim, 'integrar' aqueles que foram retirados do convívio de suas culturas tradicionais à sociedade nacional. (MUNDURUKU, 2012, p. 30-31).

Porém, é preciso entender essa divisão em paradigmas como algo meramente didático, porque, apesar da legalização da tutela integracionista só acontecer na primeira metade do século XIX, já nos primeiros anos da colonização eram colocadas em prática políticas com vistas à diluição da diferença representada pelos indígenas em uma cultura que se pretendia branca e eurocêntrica. Nesse sentido Munduruku afirma que

A catequese e a educação ministradas aos povos indígenas significaram, na verdade, o emprego de outro tipo de violência contra esses povos, configurada pela imposição de valores sociais, morais e religiosos, acarretando a desintegração e a consequente destruição de incontáveis sociedades indígenas, o que caracteriza o etnocídio, um processo diverso do genocídio, porém com resultados igualmente nefastos para os povos dominados. (MUNDURUKU, 2012, p. 29).

Destarte, os mesmos jesuítas que abonavam o assassinato dos indígenas valendo-se de argumentos religiosos, trabalhavam para integrá-los aos modos de vida mais adequados aos interesses econômicos da metrópole. Essa tarefa era cumprida especialmente através da organização das práticas de trabalho (limítrofes em relação à escravidão), do ensino da língua portuguesa e dos fundamentos da fé católica. Na visão desses missionários, os indígenas eram selvagens sem nenhuma cultura, crença e conhecimentos e, portanto aptos a serem civilizados, assimilados a uma modelo de sociedade ideal. Já na Carta de Achamento do Brasil, o escrivão Pero Vaz de Caminha registra essa vontade assimilacionista:

se os degredados, que aqui hão de ficar aprenderem bem a sua fala e os entenderem, não duvido que eles, segundo intenção de Vossa Alteza, se hão de fazer cristãos e crer em nossa santa fé, à qual praza a Nosso Senhor que os traga, porque, certo, esta gente é boa e de boa simplicidade. E imprimir-se-á ligeiramente neles qualquer cunho, que lhes quiserem dar. (SILVA, 2014, p. 52).

Porém, frustrando os vários projetos civilizadores que visavam ao desaparecimento de suas culturas, os indígenas brasileiros atuaram como força capaz nas relações de poder que se estabeleceram assimetricamente, de modo que conseguiram chegar ao final da primeira década do século XXI com um contingente estimado em quase novecentos mil indivíduos 
segundo o Censo do Instituto Brasileiro de Geografia e Estatística (IBGE). No entanto, é preciso considerar que, por ocasião da invasão, segundo algumas estimativas, havia de cinco a oito milhões de indivíduos distribuídos em torno de novecentos grupamentos étnicos, falando cerca de mil e trezentas línguas ${ }^{1}$, habitando o território que viria a ser o Brasil. Assim, na análise mais simplista dos efeitos da colonização portuguesa, será necessário admitir diversas violências, que vão desde o extermínio físico por meio de estratégias variadas até a destruição das formas próprias de vida dos povos ditos originários.

Nesse sentido, o professor Francisco Eduardo Torres Cancela, na tese de doutorado em história pela Universidade Federal da Bahia (2012), “De Projeto a processo colonial: índios, colonos e autoridades régias na colonização reformista da antiga capitania de Porto Seguro (1763-1808)”, a partir da uma leitura crítica de documentos variados do período em questão, faz importantes inferências em prol da defesa do protagonismo dos povos indígenas no processo de implantação do projeto de colonização da referida região, em contraposição às teses que apresentam os indígenas ou como vítimas indefesas que sucumbem diante da perversidade do invasor ou que resistem heroicamente à invasão desse outro. Cancela mostra que a permanência dos indígenas na região abrangida pela antiga capitania foi conquistada por eles mesmos através de múltiplas e inteligentes táticas de sobrevivência às violentas ações das empreitadas colonizadoras levadas a cabo no país.

Porém, os povos sobre os quais, de variadas maneiras, muito já se falou, enquanto eles mesmos permaneciam amordaçados, "destinados a desaparecer”, subalternizados por estratégias políticas engendradas para promover esse desaparecimento, decidiram falar do lugar daqueles que sofreram a barbárie, produzir novos enunciados através da literatura. Para Deleuze e Guattari (2014, p. 151), “a literatura [é] como relógio que adianta” e é "tarefa do povo" e "a enunciação literária a mais individual é um caso particular de enunciação coletiva”. Parece-nos, então, que é essa voz coletiva que se coloca a serviço de um contar longamente silenciado e da recontagem de uma história, que foi narrada conforme a conveniência daqueles cujas práticas foram impostas a partir dos mais diferenciados signos da violência.

Partimos do pressuposto de que as narrativas ameríndias produzem outras expressões de autoafirmação de suas presenças na constituição histórica do país. Recorrem a poéticas que inscrevem uma "economia do dom (de generosidades como revanche), uma estética do golpe (de operações de artistas) e uma ética da tenacidade (mil maneiras de negar à ordem estabelecida, o estatuto da lei, de sentido ou fatalidade)" (CERTEAU, 1998, p. 88). As diferentes práticas literárias indígenas configuram artes de fazer, que combinam o questionamento das representações vigentes nos cânones literários, com atos de dizer a presença como outro.
${ }^{1}$ Informações fornecidas pelo filósofo indígena Daniel Munduruku em Mundurukando 2 (2017). Os números aproximam-se muito do que é encontrado em sites informativos. 


\section{Dos essencialismos eurocêntricos às poéticas ameríndias}

As narrativas da barbárie - ou da vitória, nos dão a ver um povo derrotado, vencido pelas armas, pelas epidemias, pela exploração e, em último caso, pela tecnologia. É oportuno trazer no espaço desta reflexão o romance Iracema, do escritor brasileiro José de Alencar, publicado em 1865, já que este constitui um dos cânones da literatura brasileira sobre os índios. Através da saga de Martin, o guerreiro branco acolhido pela "virgem dos lábios de mel”, Iracema, Alencar conta a derrota dos povos indígenas brasileiros ante a supremacia de uma cultura sobre outra tida como exótica, mítica e sem nenhuma chance de sobrevivência diante da modernidade de um país que ora se construía.

Pousando a criança nos braços paternos, a desventurada mãe desfaleceu, como a jetica se lhe arrancam o bulbo. O esposo viu então como a dor tinha consumido seu belo corpo; mas a formosura ainda morava nela, como o perfume na flor caída do manacá.

Iracema não se ergueu mais da rede onde a pousaram os aflitos braços de Martim. O terno esposo, em quem o amor renascera com o júbilo paterno, a cercou de carícias que encheram sua alma de alegria, mas não a puderam tornar à vida: o estame de sua flor se rompera.

(...)

O doce lábio emudeceu para sempre; o último lampejo despediu-se dos olhos baços. (ALENCAR, 2004, p. 64-65).

Iracema, anagrama de América, muito nos diz do projeto colonizador empreendido contra e sobre os povos indígenas brasileiros: diante do branco portador dos valores que a partir daquele momento prevaleceriam, a alma indígena que guardava “o segredo da Jurema” desfalece, a voz guerreira da filha de Araquém, pajé Tabajara, é emudecida para sempre e seu povo enfim se curva diante da fé católica:

Muitos guerreiros de sua raça acompanharam o chefe branco, para fundar com ele a mairi ${ }^{2}$ dos cristãos. Veio também um sacerdote da religião, para plantar a cruz na terra selvagem.

Poti foi o primeiro que ajoelhou aos pés do sagrado lenho. Não sofria ele que nada mais o separasse de seu irmão branco. Deviam ter ambos um só deus, como tinham um só coração. (ALENCAR, 2004, p. 65).

No entanto, após quase cinco séculos da invasão portuguesa, os povos indígenas retomam sua palavra para dizer de sua existência e de sua resistência a uma dominação que de fato nunca se consolidou. $\mathrm{O}$ antropólogo brasileiro Darcy Ribeiro, após longa e cuidadosa pesquisa no contexto de um estudo do impacto da civilização sobre os grupos indígenas brasileiros do século XX, elaborado para a Organização das Nações Unidas para a Educação, Ciência e Cultura - UNESCO, concluiu que 
Nenhum grupo indígena jamais foi assimilado. É uma ilusão dos historiadores que trabalham com documentação escrita a suposição de que onde havia uma aldeia de índios e onde floresceu, depois, uma vila brasileira, tenha ocorrido continuidade, uma se convertendo na outra. Em todos os casos examinados por nós, numerosíssimos, isso não sucedeu. Os índios foram morrendo, vítimas de toda sorte de violência, e uma população neobrasileira foi crescendo no antigo território tribal, onde se implantou uma forma totalmente nova de vida e criou sua própria identificação étnica. (RIBEIRO, 2004, p. 12).

Segundo Ribeiro, o malogro do projeto teve a ver com a capacidade indígena de resistir às mudanças que lhe eram impostas e ao forte sentimento de identificação étnica, mesmo em pequenos grupos, que fazia com que lutassem até a morte para manter suas identidades, sua cultura e autonomia. Outro aspecto, segundo o antropólogo, foi a incapacidade da própria sociedade brasileira para assimilar grupos indígenas, dadas as suas dificuldades de oferecer-se a estes como alternativa atraente. Assim, o que se entende é que os povos indígenas extintos foram mesmo exterminados.

Como que para endossar a então surpreendente, e em grande parte indesejada, resposta de Ribeiro (2004), a professora e escritora indígena Graça Graúna informa que

Entre os indígenas de várias partes do mundo, a palavra é um elemento sagrado. Na visão Guarani, por exemplo, a palavra tem alma. Palavra e identidade se confundem; palavra que passa de pai para filho, dos avós para os netos; palavra carregada de água, palavra de água, palavra vinda da terra, palavra aquecida pelo fogo, palavra tão necessária quanto o ar que se respira; palavra que atravessa o tempo. (GRAÚNA, 2013, p. 173).

Então, ao contrário do que diz o discurso colonizador através da metáfora iracema (aqui desprovido do status de nome próprio), a voz indígena não emudeceu, continuou nos longes das esferas de poder, comunicando a uma geração após outra uma certa maneira de estar no mundo, uma cultura que, na acepção de Stuart Hall (2003, p.44), teórico do pós-colonial, é “uma produção”, não “uma questão de ontologia, de ser, mas de se tornar”. Assim, essa palavra de água, vinda da terra e aquecida de fogo - muitas vezes dita ao redor das fogueiras e à beira dos fornos de farinha, atravessou o tempo produzindo as culturas indígenas que resistiram ao imperativo globalizante do ocidente ${ }^{3}$, em um processo que certamente comporta inúmeras táticas de negociação onde recuos e avanços se sucedem agonisticamente.

A palavra indígena força passagem na literatura dita menor por Deleuze e Guattari (2014), no narrar da escritora e ativista ${ }^{4}$ indígena Eliane Potiguara (2004, p.127) em sua bela coletânea de textos de variados gêneros Metade cara, metade máscara, em que conta da opressão e das violências sofridas pelos povos indígenas, das lutas empreendidas por eles, das vitórias
${ }^{3}$ Talvez desnecessário dizer, mas o termo aqui define-se como lugar sociológico do poder hegemônico.

${ }^{4}$ É muito comum que os intelectuais indígenas atuem diretamente na luta por direitos, coloquem sua voz, empenhem sua palavra em nome de uma coletividade, tal como o intelectual orgânico gramsciano. 
conquistadas e, em especial, da coragem e da audácia das mulheres à frente das batalhas travadas.

Por meio da metáfora Cunhataí e Jurupiranga, narrativa da coletânea a ser brevemente discutida nesse trabalho, Potiguara narra a saga de seus ancestrais desde o momento em que os portugueses invadiram os territórios que viriam a se unificar sob o nome Brasil.

Estava Jurupiranga em seu território distante trabalhando no roçado pelo alimento diário de sua família, quando o chefe da tribo chegou gritando ao lado dos outros homens.

"Os colonizadores estão invadindo nossas terras, levando nossas mulheres e crianças, matando nossos velhos e incendiando nossas casas.”

(...)

Jurupiranga e outros homens desesperados partiram à procura de suas mulheres. Quando chegaram ao povoado dos colonos, viram centenas de indígenas de outras tribos escravizadas. (...) Atravessou rios, montanhas, vales, viu centenas de povos tombados pela guerra, viu aldeias inteiras destruídas, viu povos escravizados cabisbaixos trabalhando para os jesuítas (...) e milhares de cadáveres. (...) Sucumbiu. Esqueceu os sons de sua flauta, esqueceu os acordes de seu povo, esqueceu o ritmo dos tambores. Viajou presente, passado e futuro. Passou fome, criou calos nos pés e nas mãos, adoeceu as piores doenças dos invasores (...) mas... quando meditava, meditava e meditava, buscando sua força interior, o seu self selvagem, sua iluminação, às noites sonhava com sua esposa, com sua família, seus filhos, cânticos que não conseguia decifrar, mas percebia a existência de uma grande História interior e resistia como se fosse um rinoceronte. (POTIGUARA, 2004, p. 127-128).

O guerreiro de quem Potiguara (2004), propositalmente, não identifica a etnia, já que representa todas as nações indígenas das Américas, como é possível perceber quando ela narra que ele "viu centenas de povos tombarem à baioneta dos neo-americanos, ingleses, holandeses, franceses, espanhóis, portugueses e dos próprios brasileiros" e que "atravessou desertos no Arizona”. (POTIGUARA, 2004, p.128). Jurupiranga ganha então um potencial metonímico na narrativa literária, que encontra inequívoca correspondência no percurso do próprio movimento indígena brasileiro, em suas práticas políticas nas intensas lutas por direitos que tiveram seu marco histórico em 1970.

Por outro lado, Juripiranga inscreve posições outras que enunciam a ocasião do extermínio das populações indígenas pelos colonizadores. As localizações do trágico encontro nos atos de enunciação da personagem "permitem justapor, num mesmo quadro, espaços diferentes. Mas na série em que insinua a ocasião, a justaposição de dimensões heterônomas diz respeito ao tempo e ao espaço, ou estado e ação.” (CERTEAU, 1998, p. 159). No âmbito do texto literário, o guerreiro é ao mesmo tempo personagem e 
tática de reversão das representações do conformismo dos corpos indígenas constituídos pelos cânones celebrados como literatura nativa sobre a invenção de um Brasil, cujas bases foram fundadas, não no extermínio e na violência, mas no encontro amoroso entre povos.

Nos anos de 1970, sob a influência de uma antropologia francesa estruturalista, tendo à frente Claude Lévi-Strauss, havia uma forte tendência a um essencialismo que valorizava as permanências e invariâncias, pesquisadas nas categorias fundamentais do espírito e no inconsciente coletivo, de forma que as sociedades ditas primitivas eram vistas como a-históricas, frias, ou seja, sociedades menos sujeitas às transformações, regidas pela fixidez de uma estrutura. Nesse sentido, o sociólogo francês, Georges Balandier afirma que

O apego a uma concepção sobre as sociedades "primitivas”, que leva a tomá-las como um estado primordial das sociedades humanas, uma forma muito anterior e mais simples da vida social. Esse pressuposto implicaria em que elas se tivessem preservado em sua identidade apesar das vicissitudes sofridas, e que se tenham conservado graças a uma surpreendente determinação de "repetição" e uma "sabedoria” a conferir-lhe eficácia. (BALANDIER, 1976, p.182).

No âmbito das tradições antropológicas marcadamente eurocêntricas, o indígena transforma-se em objeto cuja manipulação se fixa no passado primitivo e na fusão de suas práticas no meio natural. Tempo e espaço, nestas tradições, colocam em suspensão a condição ontológica de designação do indígena como produto das narrativas etnológicas.

\section{Da fixação no tempo e no espaço à prescrição de identidades fixas}

O pensador francês lança, de forma contundente, um questionamento dos usos das configurações nos povos tradicionais nas ciências sociais, ao mesmo tempo em que aponta os seus efeitos na reprodução de uma 'ilusão social essencial’ (BALANDIER, 1976, p. 205), nas instituições que adotaram essa ótica social para fixar tradições e povos dentro de molduras discursivas em que não escapam religiões, ciência, literatura e agências de governos notadamente eurocêntricos.

Nessa perspectiva nasce a Fundação Nacional do Índio - FUNAI, em 1967, no intuito de representar e defender os interesses dos povos indígenas, no sentido de tutelá-los na condição de silvícolas relativamente incapazes de autorrepresentação diante da comunidade nacional, já que estes, em estágio de desenvolvimento anterior, deveriam ser paulatinamente inseridos no contexto do progresso. A respeito, o filósofo indígena Daniel Munduruku (2012, p. 35) informa que "na qualidade de tutor, incumbiu-se a FUNAI de prover as necessidades de seus tutelados, mediante a adoção de uma política paternalista e assistencialista que não se sustentou” devido 
aos escassos recursos financeiros repassados ao órgão, o que aumentou a situação de risco em que se encontravam estes povos.

Assim, desenhou-se no imaginário nacional uma imagem de "índio” que, em grande medida, ainda perdura: a do selvagem habitante nu das florestas brasileiras que vive apartado das transformações operadas pelos processos históricos desnovelados no campo da política e da cultura. Mesmo a literatura romântica, tal como a alencariana, quando parece louvar as qualidades do indígena relativas à ingenuidade, lealdade e pureza, constrói um espelho em que se reflete a imagem do atraso e da incapacidade de conviver com um outro mais evoluído e moderno, funcionando, sem dúvida, como um potente lugar de desaparecimento.

Outrossim, as populações indígenas que habitam regiões de grande proximidade física e social com populações não indígenas, enfrentam a desconfiança cotidiana quanto a autenticidade dos seus pertencimentos étnicos, sobretudo em situações de conflitos na luta pela demarcação de seus territórios e preservação de suas tradições culturais. A reprodução massificada de figurações rígidas do indígena, conferem peso e medida às distorções cognitivas que servem de referência para o julgamento do que significa ser indígena por não indígenas, agravando as situações de etnocentrismo na contemporaneidade.

\section{Das narrativas de fixação às narrativas de contestação}

Essas narrativas congregam em si os conflitos dos quais nos fala o pensador pós-colonial Homi Bhabha, ao discutir o papel do estereótipo no discurso colonial:

O fetiche ou estereótipo dá acesso a uma 'identidade' baseada tanto na dominação e no prazer quanto na ansiedade e na defesa, pois é uma forma de crença múltipla e contraditória em seu reconhecimento da diferença e recusa da mesma. Este conflito entre prazer/desprazer, dominação/defesa, conhecimento/recusa, ausência/presença, tem uma significação fundamental para o discurso colonial. (BHABHA, 2014, p.130).

O nascente Movimento Indígena, recusando o histórico de tutela e contando com o apoio de muitos parceiros não indígenas, apropriou-se do estereótipo utilizado muitas vezes para justificar o etnocídio perpetrado contra os povos indígenas, para unificar todos eles sob uma única bandeira de luta, uma vez que era preciso dar ciência à sociedade nacional dos povos indígenas que não sucumbiram às estratégias exterminacionistas e assimilacionistas. O líder indígena Ailton Krenak, em entrevista dada a Munduruku (2012, p. 197), diz que “na década de 60 e até o começo da década de 70, mesmo as pessoas mais bem informadas do Brasil, se perguntassem a elas 
sobre índios, iam dizer: "Não, índio não. Não tem. Bem, talvez tenha um ou outro aí guardado em alguma reserva pelos irmãos Vilas Boas”.

Krenak ironiza ainda o discurso colonial e joga como o modelo operante no imaginário social ao sugerir uma "vida paradisíaca” interrompida pelos invasores portugueses que, na ótica do progresso está identificada com a preguiça, a aversão ao trabalho e à noção de desenvolvimento, ao mesmo tempo desejada e rechaçada pelo sujeito do ocidente:

se não existissem os brancos aqui, a UNI ${ }^{5}$ não existiria, e eu estaria lá na minha aldeia, com o meu povo, com a minha tribo, caçando, guerreando, ${ }^{5}$ União das Nações namorando. Mas como os brancos existem, tive que trocar toda essa vida paradisíaca por uma vida chata de ficar aqui conversando com as pessoas, negociando politicamente, sendo transigente ou intransigente, sendo tolerante e, às vezes, sendo duro. (MUNDURUKU, 2012, p. 197).

A inscrição “dos brancos”, no discurso de Krenak, altera as condições de existência que situam o seu ato de dizer. A citação indica o caráter adversativo da relação entre brancos e indígenas para, em seguida, apresentar traços de contestações que sugerem, negociações, transigências e intransigências, dureza no trato com as condições de exigência vigentes. Essa alteração recorre à palavra e ao gesto para expressar lance a lance a contestação como devolução da memória daqueles e daquelas que sofrem os massacres do apagamento identitário.

Isto sugere que "a vivacidade e a precisão da devolução são indissociáveis de uma dependência em relação aos instantes e de uma vigilância que marcam com tanto mais vigor quanto menos lugar próprio têm para se proteger contra eles.” (CERTEAU, 1998, p. 164). O discurso de Kernak confere ressonâncias de contestação que também transpassam o guerreiro Jurupiranga, ou seja, as duas personagens, uma da esfera da história contemporânea, outra da ficção, interpelam a forma como a nação foi imaginada e narrada.

Não é exagero ler na narrativa de Potiguara (2004, p.128-129) esse momento histórico em que os "índios” aglutinam forças na imagem heroica de Jurupiranga: como se fosse um rinoceronte, de "casco grosso", “alma de ferro”, “mãos de aço”, persistia em sua “convicção e na sua voz interior contra os dominadores e reencontrar seu povo, reconstruí-lo para sempre na paz e amor”. Tal leitura se confirma na visão profética dessa personagem coletiva que vê guerreiros usarem a palavra em diversas línguas e serem ouvidos e respeitados, vê "o grupo indígena apresentando papeis para uns homens brancos de roupas pretas, cinzas”, “mesas cobertas de mapas de territórios indígenas definidos por eles e via negociações serem feitas objetivando a paz indígena”.

A visão de Jurupiranga dá conta das intensas mobilizações para inserção dos direitos dos povos indígenas na constituição federal de 1988, em 
especial, em um evento narrado em Metade cara, metade máscara que se tornou mundialmente conhecido, o discurso histórico do jovem Krenak em 04 de setembro de 1987, vestido de branco, falando incisiva e pausadamente, enquanto pinta o rosto de tinta de jenipapo, da "ignorância do que significa ser um povo indígena”, “do respeito aos mais fracos”, àqueles que foram difamados como inimigos do desenvolvimento do país. Mesmo que nos artigos 231 e 232 da constituição cidadã tenham sido garantidas importantes vitórias do povo indígena, o termo utilizado ainda é o apelido dado pelo colonizador, como se lê no caput do 231: "São reconhecidos aos índios sua organização social, línguas, crenças e tradições, e os direitos originários sobre as terras que tradicionalmente ocupam, competindo à União demarcá-las, proteger e fazer respeitar todos os seus bens”.

Embora índio remeta a uma perigosa e falsa generalização homogeneizante em seus efeitos, já que encobre uma diversidade composta por centenas de povos e línguas, contraditoriamente o mesmo texto, ao falar de língua, crença e tradição no plural, já admite a existência de uma multiplicidade que a categoria em questão não dá conta de comportar ${ }^{6}$. Talvez por que naquele momento o discurso da diversidade fosse ininteligível e taticamente fraco, o próprio Krenak fala do jeito de pensar e de viver de um povo indígena, de suas condições fundamentais de existência, criando uma imagem necessariamente monolítica das nações indígenas brasileiras, de alguma forma, o mesmo que Eliane Potiguara faz na literatura, até certo ponto, ao inventar Jurupiranga.

Então, o herói de Metade cara, metade máscara no período pós-constituição viu em seu sonho os povos indígenas, dispersados pelo ímpeto da violência colonizadora, serem reconhecidos e reintegrados ao seu território original; viu mulheres serem respeitadas; viu jovens indígenas nas universidades e nos espaços de poder lutando pelo reconhecimento dos direitos necessários à dignidade de seus povos. Jurupiranga viu ainda "bibliotecas inteiras recheadas de livros escritos pelos próprios indígenas”.

A narrativa de Potiguara (2004) comunica um sonho coletivo alimentado, segundo ela mesma, por meio das lembranças das histórias, dos ancestrais, da cultura e de uma tradição que permitiu “encontrar o caminho de volta” através dos séculos. Tal processo de resistência só se torna inteligível, em grande medida, se entendermos a cultura como um processo. $\mathrm{Na}$ acepção de Ulf Hannerz

apenas por estarem em movimento, sendo sempre recriados, é que os significados e as formas significativas podiam tornar-se duradouros. Levar o processo a sério quer dizer também manter a cultura em movimento, as pessoas, enquanto atores e redes de atores, têm de inventar cultura, refletir sobre ela, fazer experiências com ela, recordá-la (ou armazená-la de alguma maneira), discuti-la e transmiti-la. (HANNERZ, 1997, p. 11-12).
${ }^{6}$ Interessante ressaltar que as legislações internacionais melhor deram a ver a questão da diversidade, como é o caso da Convenção n ${ }^{\circ} 169$ da Organização Internacional do Trabalho - OIT de 1989, ao tratar já em termos de "povos indígenas”. 
A partir do entendimento dessa cultura que só pode permanecer como processo sempre em vias de se fazer, Hannerz (1997, p.14) recusa a ideia de fixidez denunciada por Bhabha (2014, p. 117) quando este afirma que o discurso colonial depende do conceito de "fixidez" na “construção ideológica da alteridade", que "a fixidez do discurso do colonialismo é um modo de representação paradoxal: conota rigidez e ordem imutável como também desordem, degeneração e repetição demoníaca”, ao discutir a cultura como fluxo espaço-temporal, em oposição ao discurso que reporta a ela como algo estático, em que maneiras de viver podem ser nomeadas como tradicionais ou retrógradas. As metáforas advindas do uso do termo apontam para a cultura como redemoinho, volumes diversos, afastamentos, viscosidades e confluências, mas, em nosso entendimento, impossível de represamentos, sob pena de estagnação e morte.

A partir do entendimento da cultura como vir a ser, como fluxo, sem desconsiderar os limites e zonas fronteiriças, esses locais em que ocorrem as trocas, onde as traduções acontecem e o trans e o inter são intensamente (re)negociados, quase cinco décadas depois da eclosão de um movimento indígena organizado sob a força de um estereótipo, os povos indígenas lutam para desconstruir o apelido dado pelo invasor, desembrulhando-o, desmontando-o para evidenciar e denunciar o que ele traz de simbólico, as ideias que orbitam em seu campo semântico. A recusa ao termo índio acontece ao mesmo tempo em que se reivindica uma diversidade que tal palavra encobre, ao mesmo tempo em que movimentos anti-indígenas se apropriam dele para negar os direitos dos povos que trazem em si as marcas das relações inter-étnicas, como é o caso de boa parte dos povos do nordeste brasileiro, a exemplo dos Pataxó ${ }^{7}$.

Além de atrair para si significados negativos relacionados à preguiça, à incompetência gerencial, à falta de higiene, à incapacidade de compreensão e selvageria, o vocábulo índio unifica romanticamente a imagem dos sujeitos indígenas. Fica então explicitada a influência da literatura produzida por Alencar e outros românticos do século XIX, cujas escritas ganharam espaço em produções veiculadas em diversas mídias, incluindo a televisão, através de filmes e telenovelas que fizeram circular essa figura una, sem contradições ou diferenças de “o índio brasileiro”: bom, ingênuo, tolo, tez amorenada, cabelos lisos e negros, pele pintada, ora encantado, ora assustado com o incrível mundo moderno dos brancos.

\section{Conclusões}

Por meio dos dois modelos de índio, tanto o alencariano quanto o de inimigo da nação, os povos indígenas brasileiros são violentados e têm seus direitos sistematicamente negados pelo Estado e questionados pela sociedade. Em 2013, durante um dos períodos mais críticos da guerra por demarcação
${ }^{7}$ Povo que convive com não indígenas desde o século XVI e que hoje habita o extremo sul da Bahia e norte de Minas, estando entre os povos em processo de retomada étnica e territorial. 
do território indígena Serra do Padeiro, no intuito de colocar a população local e nacional contra os Tupinambá ${ }^{2}$, as partes contrárias à demarcação veicularam a ideia de que não se tratava de índios verdadeiros, eram "falsos índios”, o que foi dito através das mídias impressas, digitais, da televisão e até de outdoors. Ser um índio falso tem a ver com os sinais diacríticos impressos nos corpos que evidenciam as relações com descendentes de brancos e negros, assim como o acesso e uso das tecnologias de informação e comunicação da atualidade, nas palavras do antropólogo João Pacheco de Oliveira (1998, p.5), sujeito desprovido “de forte contrastividade cultural”.

Diante de situações como essas, torna-se um imperativo a luta por afirmação e reconhecimento da diversidade de povos indígenas que há no Brasil, visto que os espaços de visibilidade ainda são raros e tímidos. Para Spivak (2010) em “Pode o subalterno falar?”, não basta que o subalterno fale, é preciso que ele seja ouvido. Por isso, talvez o papel do movimento indígena brasileiro para esses dias, seja o de educar as pessoas para escuta. Nesse sentido o líder Carlos Taukane (MUNDURUKU, 2012, p.198), falando da atuação do Movimento, afirma que

A gente precisa ser ainda mais (...) na medida em que nós indígenas tivermos competência para colocarmos nossas questões culturais de forma mais clara, diferenciada, para que possamos revelar a diferença que há entre nós indígenas e o tratamento que os brancos ainda reproduzem sobre nossa gente [...] são coisas pequenas, mas que ainda têm um sentido de deboche, e a gente tem que ter competência para colocar essas questões, pois elas contribuem para uma imagem negativa sobre as populações indígenas, a qual ainda está no imaginário, no inconsciente de muita gente da sociedade. A gente precisa ser mais educativo para o mundo do branco no que diz respeito ao nosso povo: temos que usar todos os mecanismos para nos prepararmos mais para acelerar esse processo educativo.(MUNDURUKU, 2012, p. 198).

Através do posicionamento do guerreiro taukane, retornamos a Deleuze e Guattari (2014) para afirmar a potência da literatura menor como mecanismo de educação que pode forçar a vista e a escuta para a realidade diversa dos povos indígenas brasileiros, provocar a problematização da imagem idealizada e unificada do índio brasileiro de Alencar e da canção de Roberto (daquele, o rei dos cantores), desconstruindo-a, colocando-a em ruínas, para que outras sejam construídas em seu lugar, sem pretensão a essências constituidoras de identidades fechadas.

Metade cara, metade máscara cria um espaço de ver e ouvir, através de belas metáforas, a saga do povo indígena brasileiro. A escritora encerra a narrativa com a cena do reencontro entre Jurupiranga e Cunhataí, que após séculos de separação e dor pode finalmente amar seu homem (2004, p.136): “Cunhataí vai até o leito do marido e diz: Desperta Jurupiranga! (...) Vem que te sonhei a noite toda (...) Vem, que vou me pintar com urucum, Vou
${ }^{8}$ Sobre a luta Tupinambá pelo direito de habitar seu território imemorial: https:// www.cartacapital. com.br/sociedade/oretorno-a-terra-dostupinambas-5708. html 
me encher de mil colares pra te esperar pro ritual (...) Me afoga em teus beijos, teus quentes desejos.”

Então, a literatura menor enfrenta o estatuto do cânone, para contar a história de um povo vencido ${ }^{9}$, sob a rubrica de uma escrita potencialmente coletiva e transformadora, já que inquire as formas da vitória de quem se impôs por força dos mais variados mecanismos de guerra, uma vez que evidencia e valoriza as resistências, as micronarrativas aparentemente dissolvidas nas grandes e lineares narrativas dos vencedores. Enquanto em Iracema o lugar do encontro é também o da subjugação e morte, em Jurupiranga e Cunhataí o encontro é o lugar que inaugura um tempo novo, em que outras maneiras de perceber e saber o outro serão possíveis.

\section{Referências}

ALARCON, D. O retorno à terra dos Tupinambás. Carta Capital. 2013. Disponível em: < https:/www.cartacapital.com.br/sociedade/o-retorno-aterra-dos-tupinambas-5708.html>. Acesso em: 10 ago. 2018.

ALENCAR, J. Iracema. São Paulo: Scipione, 2004.

BALANDIER, G. Antropo-lógicas. Tradução de Oswaldo Elias Xidieh. São Paulo, Cultrix, Editora da Universidade de São Paulo, 1976.

BHABHA, H. K. O local da cultura. Tradução de Myriam Ávila; Eliana Lourenço de Lima Reis e Gláucia Renate Gonçalves. 2. ed. Belo Horizonte: UFMG, 2014.

CANCELA. Francisco Eduardo Torres. De projeto a processo colonial: índios, colonos e autoridades régias na colonização reformista da antiga capitania de Porto Seguro (1763 - 1808). 2012. 338f. Tese (Doutorado em História). Faculdade de Filosofia e Ciências Humanas, Universidade Federal da Bahia, Salvador, 2012.

CERTEAU, M. A invenção do Cotidiano: Artes do Fazer. Tradução de Ephraim Ferreira Alves. 3. ed. Petrópolis: Vozes, 1998.

CONVENÇÃO No 169 SOBRE POVOS INDÍGENAS E TRIBAIS E RESOLUÇÃO REFERENTE À AÇÃO DA OIT. Organização Internacional do Trabalho. Brasília: OIT, 2011.

DELEUZE, G.; GUATTARI, F.. Kafka: por uma literatura menor. Tradução de Cíntia Vieira da Silva. Belo Horizonte: Autêntica, 2014.

FOUCAULT, M. Em defesa da sociedade. Tradução de Maria Ermantina de Almeida Prado Galvão. 2. ed. São Paulo: Martins Fontes, 2010.

GRAÚNA, G. Contrapontos da literatura indígena contemporânea no

Brasil. Belo Horizonte: Mazza Edições, 2013.
${ }^{9}$ Refiro-me aqui a Foucault (2010, p. 59), quando este discute que na "história contada pelos vencedores” não cabe a dos vencidos e questiona o postulado de que "a história dos grandes contém a fortiori a história dos pequenos, o postulado de que a história dos fortes traz consigo a história dos fracos”. 
HALL, S. Da diáspora: identidades e mediações culturais. Tradução de Adelaine La Guardia Resende et al. Belo Horizonte: UFMG, 2003.

HANNERZ, U. Fluxos, Fronteiras, Híbridos: Palavras-chave da Antropologia Transnacional. Mana, Rio de Janeiro, v.3, n.1, p. 7-39, 1997.

LANDER, E. A colonialidade do saber: eurocentrismo e ciências sociais. In: Perspectivas latino-americanas. Edgard Lander (Org). Colección Sur Sur, Clacso, Ciudad Autônoma de Buenos Aires, Argentina. 2005.

MUNDURUKU, D. O caráter educativo do movimento indígena brasileiro (1970-1990). São Paulo: Paulinas, 2012.

Mundurukando 2: sobre vivências, piolhos e afetos: roda de conversa com educadores. São Paulo: UK'A Editorial, 2017.

OLIVEIRA, J. P. Uma etnologia dos “índios misturados”? Situação colonial, territorialização e fluxos culturais. Mana, Rio de janeiro, v.4, n. 1, p. 47-77, 1998.

POTIGUARA, E. Metade cara, metade máscara. São Paulo: Global, 2004.

RIBEIRO, D. Os índios e a civilização: a integração das populações indígenas no Brasil Moderno. São Paulo: Companhia das Letras, 2004.

SILVA, V. L. Leitura e interculturalidade em uma escola Pataxó no Prado. 2014. 133 f. Dissertação (Mestrado em Memória: Linguagem e Sociedade). Departamento de Letras, Pontifícia Universidade Católica do Rio de Janeiro, Rio de Janeiro, 2014. Disponível em: <https://www. maxwell.vrac.puc-rio.br/24752/24752.PDF>. Acesso em: 01 ago. 2018.

SPIVAK, G. C. Pode o subalterno falar? Tradução de Sandra Regina Goulart Almeida; Marcos Pereira Feitosa e André Pereira Feitosa. Belo Horizonte: UFMG, 2010.

Recebido em agosto/2018.

Aceito em dezembro/2018. 